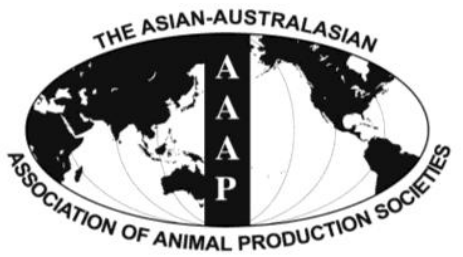

Asian-Aust. J. Anim. Sci.

Vol. 26, No. $4:$ 523-528 April 2013

http://dx.doi.org/10.5713/ajas.2012.12539

www.ajas.info

pISSN $1011-2367$ elSSN 1976-5517

\title{
Effects of Branched-chain Amino Acids on In vitro Ruminal Fermentation of Wheat Straw
}

\author{
Hui Ling Zhang, Yong Chen*, Xiao Li Xu and Yu Xia Yang \\ The Xinjiang Key Laboratory of Meat and Milk-Production Herbivore Nutrition, \\ Xinjiang Agricultural University, Urumqi 830052, China
}

\begin{abstract}
This study investigates the effects of three branched-chain amino acids (BCAA; valine, leucine, and isoleucine) on the in vitro ruminal fermentation of wheat straw using batch cultures of mixed ruminal microorganisms. BCAA were added to the buffered ruminal fluid at a concentration of $0,2,4,7$, or $10 \mathrm{mmol} / \mathrm{L}$. After $72 \mathrm{~h}$ of anaerobic incubation, $\mathrm{pH}$, volatile fatty acids (VFA), and ammonia nitrogen $\left(\mathrm{NH}_{3}-\mathrm{N}\right)$ in the ruminal fluid were determined. Dry matter (DM) and neutral detergent fiber (NDF) degradability were calculated after determining the DM and NDF in the original material and in the residue after incubation. The addition of valine, leucine, or isoleucine increased the total VFA yields $(\mathrm{p} \leq 0.001)$. However, the total VFA yields did not increase with the increase of BCAA supplement level. Total branched-chain VFA yields linearly increased as the supplemental amount of BCAA increased ( $\mathrm{p}<0.001)$. The molar proportions of acetate and propionate decreased, whereas that of butyrate increased with the addition of valine and isoleucine $(p<0.05)$. Moreover, the proportions of propionate and butyrate decreased $(p<0.01)$ with the addition of leucine. Meanwhile, the molar proportions of isobutyrate were increased and linearly decreased $(\mathrm{p}<0.001)$ by valine and leucine, respectively. The addition of leucine or isoleucine resulted in a linear $(\mathrm{p}<0.001)$ increase in the molar proportions of isovalerate. The degradability of NDF achieved the maximum when valine or isoleucine was added at $2 \mathrm{mmol} / \mathrm{L}$. The results suggest that low concentrations of BCAA ( $2 \mathrm{mmol} / \mathrm{L})$ allow more efficient regulation of ruminal fermentation in vitro, as indicated by higher VFA yield and NDF degradability. Therefore, the optimum initial dose of BCAA for in vitro ruminal fermentation is $2 \mathrm{mmol} / \mathrm{L}$. (Key Words: Branched-chain Amino Acids, Fermentation, In vitro Culture, Wheat Straw)
\end{abstract}

\section{INTRODUCTION}

Forages are necessary for normal rumen function and provide a more cost-efficient means of feeding for ruminants. However, high proportions of structural carbohydrate found in forages limit the voluntary intake and digestion of feedstuffs by ruminants because they slow down the rates of microbial fermentation (Feng, 2004). Abundance and diversity of rumen microorganisms, particularly of cellulolytic bacteria and anaerobic fungi, are necessary to degrade the fibrous dietary components (Wilson, 2008). Thus, a method for promoting the growth of fiber-degrading microorganisms would be beneficial in increasing the degradation of cellulose and hemicellulose in the rumen.

Most ruminal cellulolytic microorganisms, such as Ruminococcus albus, Ruminococcus flavefaciens,

\footnotetext{
* Corresponding Author: Yong Chen. Tel: +86-991-8763895, Fax: +86-991-8763890, E-mail: animbiotech@yahoo.com.cn Submitted Oct. 1, 2012; Accepted Nov. 18, 2012; Revised Dec. 17, 2012
}

Fibrobacter succinogenes, and Butyrivibio fibrisolvents, require branched-chain volatile fatty acids (BCVFA, i.e., isobutyric, isovaleric, valeric, and 2-methylbutyric acids) for growth (Feng, 2004). Ruminal BCVFA primarily originates from dietary protein or recycling of bacterial protein by ruminal oxidative deamination and decarboxylation of valine, leucine, and isoleucine (Tedeschi et al., 2000). Previous studies have shown that BCVFA can improve apparent dry matter digestibility and microbial growth, and enhance microbial functions and enzyme activities in the rumen of sheep (Andries et al., 1990; Moharrery, 2004). Dietary supplementation with BCVFA improves rumen fermentation and enhances digestion of cattle (Liu et al., 2008, 2009).

BCVFA are used to synthesize branched-chain amino acids (BCAA, i.e., valine, leucine, and isoleucine) by ruminal microorganisms (Allison et al., 1962). Several researchers have demonstrated that amino acids (AA) are often stimulatory for ruminal microorganisms, even when ammonia and carbohydrates exceed the requirements (Cotta 
and Russell, 1982; Argyle and Baldwin, 1989). These results indicate that AA directly affects the growth rate of rumen microbes.

Results of in vitro ruminal fermentation trials have shown that BCVFA increase forage neutral detergent fiber (NDF) digestibility more than the control, and BCAA increase the digestibility over the corresponding BCVFA. These results indicate that ruminal microorganisms could benefit more by direct provision of BCAA rather than the corresponding BCVFA (Yang, 2002). However, the optimum doses of each BCAA for rumen fermentation and substrate degradation are still unknown. Little information is available about the effects of BCAA on ruminal fermentation in vitro and in vivo, although beneficial effects of BCAA on fibrous material degradation in in vitro trials have been reported (Mir et al., 1991; Yang, 2002). This study aims to examine the effect of addition of valine, leucine and isoleucine at different levels on in vitro rumen fermentation of wheat straw.

\section{MATERIAL AND METHODS}

\section{Preparation of ruminal inoculums and culture medium}

Four male Kazak sheep (approximately $37 \mathrm{~kg}$ each) fitted with ruminal cannulae were used as ruminal fluid donors. The sheep were maintained in individual box stalls $(1 \times 1.2 \mathrm{~m}, 0.8 \mathrm{~m}$ high $)$ and fed a wheat straw-based diet (712 $\mathrm{g}$ of wheat straw, $216 \mathrm{~g}$ of ground corn, $46 \mathrm{~g}$ of cottonseed meal, $15 \mathrm{~g}$ of soybean meal, $3.5 \mathrm{~g}$ of limestone, $2.4 \mathrm{~g}$ of calcium phosphate, $1.2 \mathrm{~g}$ of urea, $3.4 \mathrm{~g}$ of salt, $0.5 \mathrm{~g}$ of premix per kg dry matter) ad libitum. The sheep were fed in equal portions twice daily at 09:30 and 21:30 h. Fresh water was provided for free access. Before the morning feeding, ruminal contents were taken via the rumen cannulae and squeezed through four layers of gauze to remove feed particles. The filtered rumen fluid was transferred into a pre-warmed $\left(39^{\circ} \mathrm{C}\right)$ thermos and gassed with $\mathrm{CO}_{2}$. The well-mixed and $\mathrm{CO}_{2}$-flushed rumen fluid was then added $(1: 3 \mathrm{vol} / \mathrm{vol})$ to a pre-reduced medium containing $0.1 \mathrm{ml} / \mathrm{L}$ of micromineral solution, $212 \mathrm{ml} / \mathrm{L}$ of macromineral solution, $212 \mathrm{ml} / \mathrm{L}$ of buffer solution, $1 \mathrm{ml} / \mathrm{L}$ of resazurin solution and $44.9 \mathrm{ml} / \mathrm{L}$ of reducing agent, as described by Longland et al. (1995).

\section{Substrate, incubation and samples}

Samples of wheat straw $(1.00 \mathrm{~g})$ were weighed into $125-\mathrm{ml}$ serum bottles. Weighed valine, leucine, or isoleucine (Sigma Chemical, St. Louis, MO, USA) was added to each fermentation bottle to achieve a final concentration of $2,4,7$, or $10 \mathrm{mmol} / \mathrm{L}$. Buffered ruminal fluid $(100 \mathrm{ml})$ was added into each bottle under $\mathrm{CO}_{2}$ flushing. Bottles were fitted with stoppers, sealed, and incubated at $39^{\circ} \mathrm{C}$ in a water bath shaker set at $100 \mathrm{rpm}$.
Bottles without BCAA were designated as controls. Blanks contained only buffered ruminal fluid. The in vitro fermentation experiments for each AA were run three times, and each run contained three replicates and their respective blanks for each treatment.

After $72 \mathrm{~h}$ of incubation, fermentation was stopped by cooling in tap water. The bottles were uncapped and the final $\mathrm{pH}$ of each bottle was immediately measured with a pH meter (model FE20; METTLER TOLEDO, Shanghai, China). The content of each bottle was filtered through a nylon bag $(100 \mu \mathrm{m}$ pore size). The substrate residue was collected for the determination of dry matter (DM) and NDF. A 10-ml sample of each filtered fermentation fluid was collected and stored at $-20^{\circ} \mathrm{C}$ for subsequent analysis of ammonia nitrogen $\left(\mathrm{NH}_{3}-\mathrm{N}\right)$ and volatile fatty acids (VFA).

\section{Chemical analysis}

The substrate and residues were dried at $65^{\circ} \mathrm{C}$ for $48 \mathrm{~h}$ to determine DM. NDF was analyzed using an automatic fiber analyzer (model ANKOM 2000i; ANKOM Technology, Fairport, New York, USA) without heat-stable amylase (Ferreira and Mertens, 2007). The neutral detergent solution contained sodium sulfite and the residues were not corrected for residual ash. DM degradability and NDF degradability of wheat straw were calculated after determining DM and NDF in the original material and in the residue after incubation.

$\mathrm{NH}_{3}-\mathrm{N}$ concentration was measured via a colorimetric method modified by Maitisaiyidi et al. (2012). The concentrations of VFA in the fermentation fluid were determined by gas chromatography (Filípek and Dvořák, 2009) using crotonic acid as the internal standard with a gas chromatograph (model GC-2010; SHIMADZU Corporation, Kyoto, Japan).

\section{Statistical analysis}

Data were analyzed using the general linear models from PASW Statistics 18.0 software according to $Y_{i j}=\mu+\alpha_{i}$ $+\beta_{j}+\varepsilon_{i j}$, where $Y_{i j}$ is an observation; $\alpha_{i}$ is the effect of different inclusion levels of BCAA; $\beta_{j}$ is the effect of incubation runs; and $\varepsilon_{\mathrm{ij}}$ is the residual error. Inclusion level and incubation runs were used as fixed and random factors, respectively. Least square means were calculated and presented throughout. Statistical significance was considered at $\mathrm{p} \leq 0.05$ and tendency was considered at $0.05<\mathrm{p} \leq 0.1$. The effect of BCAA dosage was tested for linear, quadratic, and cubic effects.

\section{RESULTS}

\section{Effects of valine on in vitro ruminal fermentation}

The data of ruminal fermentation characteristics and substrate degradability in response to supplemental valine 
Table 1. Effect of different concentrations of valine on the ruminal fermentation characteristics, DM and NDF degradability of wheat straw in vitro ${ }^{1}$

\begin{tabular}{|c|c|c|c|c|c|c|c|c|c|}
\hline \multirow{2}{*}{ Item } & \multicolumn{5}{|c|}{ Valine $(\mathrm{mmol} / \mathrm{L})$} & \multirow{2}{*}{ SEM $^{2}$} & \multicolumn{3}{|c|}{ Probability } \\
\hline & 0 & 2 & 4 & 7 & 10 & & Linear & Quadratic & Cubic \\
\hline$\overline{\mathrm{pH}}$ & 6.50 & 6.49 & 6.51 & 6.50 & 6.50 & 0.013 & 0.598 & 0.882 & 0.692 \\
\hline $\mathrm{NH}_{3}-\mathrm{N}(\mathrm{mmol} / \mathrm{L})$ & 17.37 & 17.09 & 17.56 & 19.52 & 17.60 & 0.341 & 0.211 & 0.543 & 0.056 \\
\hline Total VFA $(\mathrm{mmol} / \mathrm{L})^{3}$ & 58.73 & 75.31 & 70.35 & 71.73 & 74.54 & 1.226 & $<0.001$ & $<0.001$ & $<0.001$ \\
\hline $\mathrm{BCVFA}(\mathrm{mmol} / \mathrm{L})^{4}$ & 3.16 & 5.64 & 4.68 & 4.92 & 5.38 & 0.227 & $<0.001$ & 0.001 & $<0.001$ \\
\hline Acetate $(\mathrm{C} 2)(\mathrm{mol} / 100 \mathrm{~mol})$ & 63.20 & 60.63 & 61.07 & 61.51 & 61.45 & 0.275 & 0.107 & 0.012 & 0.034 \\
\hline Propionate $(\mathrm{C} 3)(\mathrm{mol} / 100 \mathrm{~mol})$ & 22.09 & 21.83 & 21.80 & 21.54 & 21.43 & 0.297 & 0.004 & 0.897 & 0.853 \\
\hline Butyrate (mol/100 mol) & 9.34 & 10.00 & 10.49 & 10.10 & 9.94 & 0.094 & 0.011 & $<0.001$ & 0.405 \\
\hline Isobutyrate $(\mathrm{mol} / 100 \mathrm{~mol})$ & 2.15 & 3.32 & 3.04 & 3.51 & 3.97 & 0.213 & $<0.001$ & 0.341 & 0.023 \\
\hline Isovalerate $(\mathrm{mol} / 100 \mathrm{~mol})$ & 1.86 & 2.58 & 2.14 & 1.99 & 1.90 & 0.067 & 0.166 & 0.004 & 0.002 \\
\hline Valerate (mol/100 mol) & 1.35 & 1.64 & 1.46 & 1.34 & 1.31 & 0.032 & 0.032 & 0.009 & 0.004 \\
\hline $\mathrm{C} 2: \mathrm{C} 3$ & 2.89 & 2.71 & 2.81 & 2.87 & 2.88 & 0.046 & 0.561 & 0.116 & 0.171 \\
\hline DM degradability (g/kg DM) & 434.0 & 484.3 & 442.9 & 460.3 & 448.7 & 7.21 & 0.897 & 0.194 & 0.140 \\
\hline NDF degradability (g/kg NDF) & 272.5 & 379.3 & 308.3 & 321.9 & 313.4 & 11.55 & 0.728 & 0.148 & 0.054 \\
\hline
\end{tabular}

${ }^{1}$ Mean values. ${ }^{2}$ SEM $=$ Standard error of the mean.

${ }^{3}$ Total VFA, Total concentration of acetate, propionate, butyrate, isobutyrate, isovalerate, and valerate.

${ }^{4} \mathrm{BCVFA}$, Total concentration of isobutyrate, isovalerate, and valerate.

are presented in Table 1 . The values of the final $\mathrm{pH}$ of the medium were unaffected by valine supplementation. The ammonia $\mathrm{N}$ tended to increase cubically $(\mathrm{p}=0.056)$ with valine dosage. Compared with the control, valine at 2 $\mathrm{mmol} / \mathrm{L}$ or greater increased total VFA production $(\mathrm{p}<0.001)$. However total VFA yields did not increase with the increase of valine supplement level. As expected, the addition of valine resulted in an increase in total BCVFA $(\mathrm{p}<0.001)$. The molar percentages of acetate and propionate decreased with the addition of valine (quadratic response $p$ $=0.012$ and linear response $p=0.004$, respectively). The molar proportions of butyrate, isobutyrate, and isovalerate increased in a quadratic $(\mathrm{p}<0.001)$, linear $(\mathrm{p}<0.001)$, and cubic fashion $(\mathrm{p}=0.002)$, respectively, as the valine concentration increased. The molar proportion of valerate cubically changed $(\mathrm{p}=0.004)$ with valine concentration. The ratios of acetate to propionate $(\mathrm{C} 2: \mathrm{C} 3)$ were not statistically different at any level of added valine. DM degradability was not affected by the addition of valine, whereas NDF degradability of wheat straw tended to increase in a cubic fashion $(\mathrm{p}=0.054)$.

\section{Effects of leucine on in vitro ruminal fermentation}

The effects of different concentrations of leucine on the ruminal fermentation characteristics and substrate degradability are shown in Table 2. Leucine treatment tended to increase the final $\mathrm{pH}$ linearly $(\mathrm{p}=0.055)$. Ammonia $\mathrm{N}$ concentration and total VFA production increased in a linear $(\mathrm{p}=0.033)$ and quadratic fashion $(\mathrm{p}=$ 0.001 ) when leucine was incorporated into the medium. Total concentration of BCVFA linearly increased with the increase in the level of leucine supplementation $(\mathrm{p}<0.001)$.
In terms of individual VFA, the molar proportion of acetate was affected by the addition of leucine in a linear fashion $(p<0.001)$. All molar percentages of propionate, butyrate, and isobutyrate decreased $(p<0.01)$, whereas that of isovalerate linearly increased, as the amount of leucine increased $(\mathrm{p}<0.001)$. The molar proportions of valerate changed in a quadratic fashion $(\mathrm{p}<0.001)$ as leucine concentrations increased. C2:C3 quadratically increased as the leucine concentration increased $(\mathrm{p}=0.001)$. No difference in DM degradability and NDF degradability was observed as leucine concentration increased.

\section{Effects of isoleucine on in vitro ruminal fermentation}

The effects of isoleucine on in vitro rumen fermentation of wheat straw are given in Table 3. The final $\mathrm{pH}$ and ammonia $\mathrm{N}$ concentration changed in a cubic fashion with the increase in initial isoleucine concentration $(\mathrm{p}<0.05)$. Concentrations of total VFA and BCVFA linearly increased as the supplementation dosage of isoleucine increased $(p<0.001)$. Molar proportions of acetate and propionate decreased linearly $(p<0.001)$ and cubically $(p=0.007)$ with isoleucine supplementation. Proportions of butyrate and isovalerate linearly increased with the increase in isoleucine concentration $(\mathrm{p}<0.001)$. The molar proportion of isobutyrate increased at $2 \mathrm{mmol} / \mathrm{L}$ isoleucine; higher concentration of isoleucine treatment had little effect on isobutyrate production. The molar proportion of valerate was unaffected by the addition of isoleucine. Compared with the control and $2 \mathrm{mmol} / \mathrm{L}$ of isoleucine, higher concentrations of isoleucine seemed to decrease $\mathrm{C} 2 \mathrm{C}$. 3 ( $\mathrm{p}=$ 0.001). Both DM and NDF degradability tended to increase in a linear fashion ( $\mathrm{p}=0.078$ and 0.074 ) with the 
Table 2. Effect of different concentrations of leucine on the ruminal fermentation characteristics, DM and NDF degradability of wheat straw in vitro ${ }^{1}$

\begin{tabular}{|c|c|c|c|c|c|c|c|c|c|}
\hline \multirow{2}{*}{ Item } & \multicolumn{5}{|c|}{ Leucine (mmol/L) } & \multirow{2}{*}{$\mathrm{SEM}^{2}$} & \multicolumn{3}{|c|}{ Probability } \\
\hline & 0 & 2 & 4 & 7 & 10 & & Linear & Quadratic & Cubic \\
\hline$\overline{\mathrm{pH}}$ & 6.44 & 6.46 & 6.45 & 6.47 & 6.48 & 0.006 & 0.055 & 0.591 & 0.499 \\
\hline $\mathrm{NH}_{3}-\mathrm{N}(\mathrm{mmol} / \mathrm{L})$ & 21.77 & 22.67 & 23.29 & 23.32 & 23.19 & 0.252 & 0.033 & 0.162 & 0.958 \\
\hline Total VFA $(\mathrm{mmol} / \mathrm{L})^{3}$ & 66.59 & 77.58 & 74.74 & 72.44 & 71.30 & 0.872 & 0.399 & 0.001 & 0.006 \\
\hline $\mathrm{BCVFA}(\mathrm{mmol} / \mathrm{L})^{4}$ & 2.72 & 3.59 & 4.31 & 4.81 & 5.51 & 0.197 & $<0.001$ & 0.446 & 0.582 \\
\hline Acetate $(\mathrm{C} 2)(\mathrm{mol} / 100 \mathrm{~mol})$ & 66.74 & 68.56 & 67.34 & 66.37 & 65.23 & 0.477 & $<0.001$ & 0.001 & 0.024 \\
\hline Propionate $(\mathrm{C} 3)(\mathrm{mol} / 100 \mathrm{~mol})$ & 19.71 & 18.29 & 18.21 & 18.32 & 18.41 & 0.384 & 0.004 & 0.003 & 0.107 \\
\hline Butyrate (mol/100 mol) & 9.48 & 8.52 & 8.72 & 8.72 & 8.69 & 0.098 & $<0.001$ & $<0.001$ & 0.002 \\
\hline Isobutyrate $(\mathrm{mol} / 100 \mathrm{~mol})$ & 1.01 & 0.71 & 0.68 & 0.67 & 0.62 & 0.028 & $<0.001$ & $<0.001$ & $<0.001$ \\
\hline Isovalerate $(\mathrm{mol} / 100 \mathrm{~mol})$ & 1.86 & 2.87 & 3.96 & 4.78 & 5.88 & 0.276 & $<0.001$ & 0.896 & 0.769 \\
\hline Valerate $(\mathrm{mol} / 100 \mathrm{~mol})$ & 1.19 & 1.05 & 1.09 & 1.15 & 1.17 & 0.028 & 0.506 & $<0.001$ & 0.006 \\
\hline $\mathrm{C} 2: \mathrm{C} 3$ & 3.41 & 3.81 & 3.79 & 3.70 & 3.58 & 0.101 & 0.346 & 0.001 & 0.136 \\
\hline DM degradability (g/kg DM) & 449.0 & 452.7 & 444.2 & 444.5 & 431.9 & 4.36 & 0.182 & 0.521 & 0.980 \\
\hline NDF degradability (g/kg NDF) & 306.1 & 311.9 & 300.2 & 296.3 & 304.5 & 6.22 & 0.690 & 0.819 & 0.528 \\
\hline
\end{tabular}

${ }^{1}$ Mean values. ${ }^{2} \mathrm{SEM}=$ Standard error of the mean.

${ }^{3}$ Total VFA, Total concentration of acetate, propionate, butyrate, isobutyrate, isovalerate, and valerate.

${ }^{4}$ BCVFA, Total concentration of isobutyrate, isovalerate, and valerate.

supplementation of $2 \mathrm{mmol} / \mathrm{L}$ of isoleucine.

\section{DISCUSSION}

Dietary AA influences ruminal fermentation and the microbial community in vitro. When all BCAA were removed from the fermentation medium, the growth of ruminal bacteria and protozoa was inhibited, and yields of microbial protein decreased by $44.52 \%$ (Wang et al., 2008). Results from accumulated research suggest that BCAA are essential AA for the growth of ruminal microorganisms. In vivo, dietary leucine deficiency leads to a decline in the growth rate of ruminal microbes, fiber degradation, and milking performance, whether in dual-purpose cattle or Holstein cows; and the decrease is greater with the degree of deficiency (Tylutki and Fox, 1997; Juarez Lagunes et al., 1999). Compared with other AA, leucine, isoleucine, and phenylalanine are more difficult to be synthesized by rumen microorganisms (Atasoglu et al., 2004). These results suggest that considering the growth of cellulolytic bacteria and the degradation of dietary structural carbohydrates, it is necessary to supply BCAA to ruminants fed with forage based diets. The results presented in this study describe the effects of five levels of three BCAA on rumen fermentation

Table 3. Effects of different concentrations of isoleucine on the ruminal fermentation characteristics, DM and NDF degradability of wheat straw in vitro ${ }^{1}$

\begin{tabular}{|c|c|c|c|c|c|c|c|c|c|}
\hline \multirow{2}{*}{ Item } & \multicolumn{5}{|c|}{ Isoleucine (mmol/L) } & \multirow{2}{*}{$\mathrm{SEM}^{2}$} & \multicolumn{3}{|c|}{ Probability } \\
\hline & 0 & 2 & 4 & 7 & 10 & & Linear & Quadratic & Cubic \\
\hline$\overline{\mathrm{pH}}$ & 6.50 & 6.47 & 6.49 & 6.52 & 6.52 & 0.005 & 0.038 & 0.035 & 0.024 \\
\hline $\mathrm{NH}_{3}-\mathrm{N}(\mathrm{mmol} / \mathrm{L})$ & 11.66 & 10.54 & 11.26 & 12.07 & 11.77 & 0.271 & 0.135 & 0.201 & 0.014 \\
\hline Total VFA $(\mathrm{mmol} / \mathrm{L})^{3}$ & 61.40 & 67.14 & 66.49 & 68.17 & 67.10 & 0.590 & $<0.001$ & 0.003 & 0.221 \\
\hline BCVFA $(\mathrm{mmol} / \mathrm{L})^{4}$ & 2.54 & 2.91 & 3.19 & 3.82 & 3.88 & 0.126 & $<0.001$ & 0.632 & 0.305 \\
\hline Acetate $(\mathrm{C} 2)(\mathrm{mol} / 100 \mathrm{~mol})$ & 69.10 & 68.86 & 68.02 & 67.30 & 67.39 & 0.189 & $<0.001$ & 0.334 & 0.044 \\
\hline Propionate (C3) (mol/100 mol) & 20.03 & 19.81 & 20.01 & 19.90 & 19.77 & 0.028 & 0.010 & 0.455 & 0.007 \\
\hline Butyrate (mol/100 mol) & 6.73 & 6.99 & 7.19 & 7.22 & 7.06 & 0.052 & $<0.001$ & $<0.001$ & 0.529 \\
\hline Isobutyrate $(\mathrm{mol} / 100 \mathrm{~mol})$ & 1.17 & 1.28 & 1.18 & 1.15 & 1.12 & 0.015 & 0.007 & 0.016 & 0.009 \\
\hline Isovalerate $(\mathrm{mol} / 100 \mathrm{~mol})$ & 1.63 & 1.72 & 2.26 & 3.09 & 3.34 & 0.162 & $<0.001$ & 0.327 & 0.046 \\
\hline Valerate (mol/100 mol) & 1.35 & 1.33 & 1.34 & 1.33 & 1.31 & 0.008 & 0.135 & 0.968 & 0.496 \\
\hline $\mathrm{C} 2: \mathrm{C} 3$ & 3.45 & 3.48 & 3.40 & 3.38 & 3.41 & 0.010 & 0.001 & 0.298 & 0.005 \\
\hline DM degradability (g/kg DM) & 464.6 & 509.4 & 470.9 & 444.9 & 438.3 & 10.87 & 0.078 & 0.243 & 0.120 \\
\hline NDF degradability (g/kg NDF) & 270.2 & 306.2 & 283.9 & 263.5 & 252.9 & 9.03 & 0.074 & 0.835 & 0.303 \\
\hline
\end{tabular}

\footnotetext{
${ }^{1}$ Mean values. ${ }^{2}$ SEM $=$ Standard error of the mean.

${ }^{3}$ Total VFA, Total concentration of acetate, propionate, butyrate, isobutyrate, isovalerate, and valerate.

${ }^{4}$ BCVFA, Total concentration of isobutyrate, isovalerate, and valerate.
} 
and show that ruminal fermentation characteristics were somewhat changed in vitro when leucine, isoleucine, or valine was incorporated in the medium.

In the present study, the presence of valine and isoleucine at low concentration $(2 \mathrm{mmol} / \mathrm{L})$ resulted in higher degradability of NDF. Yang (2002) reported that NDF degradation of alfalfa, bermudagrass, pangolagrass hay and napiergrass silage increased by the addition of 2 $\mathrm{mmol} / \mathrm{L}$ valine or leucine. The response of forage fiber degradation by ruminal microorganisms to BCAA depends on forage type and the AA species tested. NDF degradation of alfalfa, bermudagrass, pangolagrass hay and napiergrass silage inceased by $28.8 \%, 42.0 \%, 31.3 \%$, and $38.8 \%$, respectively, when valine was incorporated in incubations (Yang, 2002). Compared with the control, DM digestibility of barley straw increased from $34.8 \%$ to $35.6 \%, 40.5 \%$, and $61.7 \%$ for valine, leucine, and isoleucine, respectively. When alfalfa hay was used as the substrate, the DM digestibility increased from $60.3 \%$ to $64.1 \%, 63.3 \%$, and $63.7 \%$ for the three AA (Mir et al., 1986). These results indicate that the effectiveness of BCAA on grass forage is higher than that on legume forage. In general, the crude protein content of legume forage is higher than that of grass forage. Natural BCAA occurring in the rumen primarily originates from dietary true protein degradation. Higher dietary protein in legumes results in more BCAA and BCVFA release by rumen microorganism fermentation. The growth of ruminal bacteria requires optimal concentrations of BCAA. Therefore, the degradation of dietary fiber may not be further improved when the added exogenous BCAA exceeds the optimal requirement. On the contrary, negative effects may occur that decrease the degradation of fiber. In this study, the DM and NDF digestibility of wheat straw tended to decline when the concentrations of added valine and isoleucine exceeded the level of $2 \mathrm{mmol} / \mathrm{L}$. This result indicates that the optimal concentration of BCAA for fiber digestion by ruminal microorganisms is approximately 2 $\mathrm{mmol} / \mathrm{L}$.

Little is known about the effects of BCAA addition on ruminal fermentation in vitro. In this study, the concentrations of total VFA, acetate, propionate, butyrate, isobutyrate, isovalerate and valerate were increased by valine or isoleucine supplementation. Except for propionate, butyrate and valerate, the concentrations of total VFA, acetate, isobutyrate and isovalerate also increased with leucine supplementation (data not shown). Our results confirm those of Zain et al. (2008), who found that production of acetate, propionate, and total BCVFA was increased by the dietary addition of BCAA. The increased VFA results from acceleration of substrate degradation and BCAA metabolism. Leucine, isoleucine and valine are extensively metabolized within the rumen by anaerobic bacteria, yielding large quantities of isovaleric, 2- methylbutyric and isobutyric acids, respectively (Feng, 2004). The three BCVFA are considered essential growth factors for most fiber-degrading microorganisms in the rumen (Yang, 2002). In this study, total branched-chain VFA yields linearly increased as the supplemental amount of BCAA was increased. Several studies have shown that ruminal fermentation is stimulated and fiber digestion is enhanced by BCVFA supplementation (Liu et al., 2009), further proving that valine or isoleucine supplementation has a tendency to increase the degradation of wheat straw in the present study.

In the three cases, the total VFA concentrations were increased by BCAA addition, however, the final $\mathrm{pH}$ either increased or remained the same. This result is fairly consistent with the report by López et al. (1999) who found that the addition of fumarate increased the final $\mathrm{pH}$ and total VFA in in vitro rumen fermentation. In another in vitro trial, $3 \mathrm{mg} / \mathrm{L}$ of cade oil increased the concentration of the total VFA from $175.4 \mathrm{mg} / \mathrm{L}$ to $189.4 \mathrm{mg} / \mathrm{L}$. However, the final $\mathrm{pH}$ remained between 6.0 to 6.1 (Busquet et al., 2006). Several factors can influence the final $\mathrm{pH}$ in rumen fermentation. The response in the present trial may be related to the buffering capacity of the medium. The medium used in this paper contained $\mathrm{Na}_{2} \mathrm{HPO}_{4} \cdot 12 \mathrm{H}_{2} \mathrm{O}$, $\mathrm{KH}_{2} \mathrm{PO}_{4},\left(\mathrm{NH}_{4}\right)_{2} \mathrm{HCO}_{3}$, and $\mathrm{NaHCO}_{3}$ (Longland et al., 1995), and these compounds are often used in preparing buffer solutions in many chemical reactions.

There is a long-held belief that cellulolytic ruminal bacteria use ammonia as their sole source of nitrogen. However, increasing evidence from research is not consistent with this conclusion (Atasoglu et al., 2001). Dehority (1963) first reported that cellulolytic ruminal bacteria $F$. succinogenes and $R$. flavefaciens have an absolute requirement for one or more AA. Later, several experiments with ruminal mixed microorganisms carried out in vivo and in vitro appear to be consistent with cellulolytic bacteria being stimulated by peptides or AA (Chikunya et al., 1996; Carro and Miller, 1999). Atasoglu et al. (2001) found that phenylalanine is essential for $F$. succinogenes growth. To date, no reports are available regarding special preference in individual species of cellulolytic bacteria for BCAA. In this study, the low level of BCAA addition produced beneficial effects on NDF degradation. Further pure culture trials are needed to identify the preference and requirement of BCAA in individual species of cellulolytic bacteria.

\section{CONCLUSIONS}

Low concentration of valine, leucine or isoleucine supplementation resulted in higher VFA production during in vitro rumen fermentation of wheat straw. If these results are confirmed in vivo, BCAA could be used as additives in 
ruminants to improve forage utilization. According to the conditions of this experiment, the optimum initial dose of BCAA is $2 \mathrm{mmol} / \mathrm{L}$.

\section{ACKNOWLEDGEMENTS}

This work was supported by the National Natural Science Foundation of China (Grant No. 31101740).

\section{REFERENCES}

Allison, M. J., M. P. Bryant and R. N. Doestch. 1962. Studies on the metabolic function of branched-chain volatile fatty acids, growth factors for ruminococci. I. Incorporation of isovalerate into leucine. J. Bacteriol. 83:523-532.

Andries, J. I., B. G. Cottyn, S. De Keersmaecker and F. X. Buysse. 1990. Effects of the addition of iso-acids to feed on ruminal fermentation, in sacco degradation of dry matter and the concentration of several blood parameters in cows. Reprod. Nutr. Dev. (Suppl 2):181s-182s.

Argyle, J. L. and R. L. Baldwin. 1989. Effects of amino acids and peptides on rumen microbial growth yields. J. Dairy Sci. 72:2017-2027.

Atasoglu, C., C. J. Newbold and R. J. Wallace. 2001. Incorporation of $\left[{ }^{15} \mathrm{~N}\right]$ ammonia by the cellulolytic ruminal bacteria Fibrobacter succinogenes BL2, Ruminococcus albus SY3, and Ruminococcus flavefaciens 17. Appl. Environ. Microbiol. 67:2819-2822.

Atasoglu, C., A. Y. Guliye and R. J. Wallace. 2004. Use of stable isotopes to measure de novo synthesis and turnover of amino acid-C and $-\mathrm{N}$ in mixed microorganisms from the sheep rumen in vitro. Br. J. Nutr. 91:235-261.

Busquet, M., S. Calsamiglia, A. Ferret and C. Kamel. 2006. Plant extracts affect in vitro rumen microbial fermentation. J. Dairy Sci. 89:761-771.

Carro, M. D. and E. L. Miller. 1999. Effect of supplementing a fibre basal diet with different nitrogen forms on ruminal fermentation and microbial growth in an in vitro semicontinuous culture system (RUSITEC). Br. J. Nutr. 82:149-157.

Chikunya, S., C. J. Newbold, L. Rode, X. B. Chen and R. J. Wallace. 1996. Influence of dietary rumen-degradable protein on bacterial growth in the rumen of sheep receiving different energy sources. Anim. Feed Sci. Technol. 63:333-340.

Cotta, M. A. and J. B. Russell. 1982. Effect of peptides and amino acids on efficiency of rumen bacterial protein synthesis in continuous culture. J. Dairy Sci. 65:226-234.

Dehority, B. A. 1963. Isolation and characterization of several cellulolytic bacteria from in vitro rumen fermentations. J. Dairy Sci. 43:217-222.

Feng, Y. L. 2004. Ruminant Animal Nutrition. Beijing: Science press.

Ferreira, G. and D. R. Mertens. 2007. Measuring detergent fibre and insoluble protein in corn silage using crucibles or filter bags. Anim. Feed Sci. Technol. 133:335-340.

Filípek, J. and R. Dvořák. 2009. Determination of the volatile fatty acid content in the rumen liquid: comparison of gas chromatography and capillary isotachophoresis. Acta Vet. Brno. 78:627-633.
Juarez Lagunes, F. I., D. G. Fox, R. W. Blake and A. N. Pell. 1999. Evaluation of tropical grasses for milk production by dualpurpose cows in tropical Mexico. J. Dairy Sci. 82:2136-2145.

Liu, Q., C. Wang, Y. X. Huang, K. H. Dong, W. Z. Yang and H. Wang. 2008. Effects of isobutyrate on rumen fermentation, urinary excretion of purine derivatives and digestibility in steers. Arch. Anim. Nutr. 62:377-388.

Liu, Q., C. Wang, Y. X. Huang, K. H. Dong, W. Z. Yang, S. L. Zhang and H. Wang. 2009. Effects of isovalerate on ruminal fermentation, urinary excretion of purine derivatives and digestibility in steers. J. Anim. Physiol. Anim. Nutr (Berl). 93:716-725.

Longland, A. C., M. K. Theodorou, R. Sanderson, S. J. Lister, C. J. Powell and P. Morris. 1995. Non-starch polysaccharide composition and in vitro fermentability of tropical forage legumes varying in phenolic content. Anim. Feed Sci. Technol. 55:161-177.

López, S., C. Valdés, C. J. Newbold and R. J. Wallace. 1999. Influence of sodium fumarate addition on rumen fermentation in vitro. Br. J. Nutr. 81:59-64.

Maitisaiyidi, T., A. Yibureyimu, Ayishayila and K. Yang. 2012. Determination of ammonia-nitrogen in ruminal fluid treated with methanol by alkaline hypochlorite-phenol spectrophotometry. Xinjiang Agric. Sci. 49:565-570.

Moharrery, A. 2004. Effect of isoacids on some rumen enzymes. J. Anim. Feed Sci. 13(Suppl.1):159-162.

Mir, P. S., Z. Mir and J. A. Robertson. 1986. Effect of branchedchain amino acids or fatty acid supplementation on in vitro digestibility of barley straw or alfalfa hay. Can. J. Anim. Sci. 66:151-156.

Mir, P. S., Z. Mir and B. M. Pink. 1991. In vitro digestibility of forages supplemented with cellulose (filter paper) and branched-chain fatty acids or amino acids. Can. J. Anim. Sci. 71:1149-1158.

Tedeschi, L. O., D. G. Fox and J. B. Russell. 2000. Accounting for ruminal deficiencies of nitrogen and branched-chain amino acids in the structure of the Cornell net carbohydrate and protein system. In: Proceedings of Cornell Nutrition Conference for Feed Manufacturers. New York: Cornell University.

Tylutki, T. P. and D. G. Fox. 1997. Application of the Cornell nutrient management planning system: optimizing herd nutrition. In: Proceedings of Cornell Nutrition Conference for Feed Manufacturers. New York: Cornell University.

Wang, M., H. Wang, H. Cao, G. Li and J. Zhang. 2008. Effects of limiting amino acids on rumen fermentation and microbial community in vitro. Agric. Sci. China. 7:1524-1531.

Wilson, D. B. 2008. Three microbial strategies for plant cell wall degradation. Ann. N. Y. Acad. Sci. 1125:289-297.

Yang, C. M. 2002. Response of forage fiber degradation by ruminal microorganisms to branched-chain volatile fatty acids, amino acids, and dipeptides. J. Dairy Sci. 85:1183-1190.

Zain, M., T. Sutardi, Suryahadi and N. Ramli. 2008. Effect of defaunation and supplementation methionine hydroxy analogue and branched chain amino acid in growing sheep diet based on palm press fiber ammoniated. Pak. J. Nutr. 7:813-816. 